\title{
Quantile Effects of Prenatal Care Utilization on Birth Weight in Argentina
}

\author{
George L. Wehby, \\ Department of Health Management and Policy, College of Public Health, University of lowa, lowa \\ City, IA, USA
}

Jeffrey C. Murray, Department of Pediatrics, College of Medicine, University of lowa, lowa City, IA, USA

Eduardo E. Castilla, ECLAMC (Latin American Collaborative Study of Congenital Malformations) at CEMIC, Buenos Aires, Argentina

ECLAMC at Instituto Oswaldo Cruz, Rio de Janeiro, Brazil

Jorge S. Lopez-Camelo, and

ECLAMC at Imbice, La Plata, Argentina

Robert L. Ohsfeldt

Health Policy \& Management, School of Rural Public Health, Texas A\&M Health Science Center, College Station, TX, USA

\section{Keywords}

Quantile regression; Instrumental variables; Prenatal care; Birth weight; Infant health; Health production

\section{Introduction}

The effects of prenatal care utilization on birth outcomes such as birth weight are commonly analyzed in order to evaluate the potential that changing utilization rates would have on improving birth outcomes. Studies using infant samples in the United States (US) have generally reported prenatal care utilization to be either ineffective or modestly effective in improving birth weight after accounting for maternal self-selection in prenatal care. An increase in birth weight mean ranging from about 1 to $35 \mathrm{gm}$ with each week prior to initiation of prenatal care has been reported across studies that used time to care initiation as the utilization measure (Rosenzweig and Schultz, 1982, 1983, 1988; Grossman and Joyce, 1990; Warner 1995, 1998; Liu, 1998; Conway and Deb, 2005). Mixed results have also been reported for number of prenatal care visits, with estimates between 1 to $45 \mathrm{gm}$ per visit (Warner, 1995, 1998; Rous et al, 2004).

Econometric studies that clearly account for self-selection in prenatal care have been rare for less developed countries, including countries in South America. Using an infant sample from Uruguay, Jewell and Triunfo (2006) reported a decrease of about $14 \mathrm{gm}$ on average with each week prior to prenatal care initiation. The study used marital status as an instrument to identify the 2SLS model and could not test for the validity of excluding marital status from the birth weight production function since the model was just identified. 
Recently, Jewell (2007) estimated the effects of prenatal care on birth weight using a combined sample from Bolivia, Brazil, Colombia and Peru and reported an increase of about $51 \mathrm{gm}$ with moving to a higher prenatal care decile (from a average of 6 to 7 visits). Only individual-level instruments were used including rural/urban residence, maternal employment, marital status, and child wantedness.

The effects of prenatal care utilization on infant health may vary by typically unobserved fetal/infant health endowments (genetic, environmental and socioeconomic) resulting in heterogeneous effects in the infant population. For instance, several studies have reported differences in prenatal care effectiveness by race (e.g. Grossman and Joyce, 1990; Joyce, 1994; Warner, 1998), and several factors that contribute to fetal health endowments such as maternal health, nutrition, stress, environment, socioeconomics, and others also vary significantly by race, providing support for the hypothesis of treatment heterogeneity by fetal endowments.

Given the complexities in measuring health endowments and that the extent of fetal health endowment is expected to correlate well with the birth weight quantile order, one approach to evaluate the existence of heterogeneous effects on birth weight is to estimate the effect of prenatal care utilization at different quantiles of the birth weight distribution. Since infants with lower health endowments are more likely to be at lower quantiles compared to infants with more endowments (holding everything else constant), estimating the effects of prenatal care utilization at lower versus higher quantiles may provide insight into the heterogeneity of prenatal care effectiveness by the extent of fetal health endowment. Potential heterogeneity in prenatal care effectiveness by the quantile order may be masked by "mean effect" analyses. Estimating effects at threshold indicators such as a binary low birth weight measure, while more clinically relevant than "mean" effects, may also mask such heterogeneity. Using US natality data, Abrevaya (2001) found larger effects of not initiating prenatal care (treated as exogenous) at lower than higher quantiles (389 versus $102 \mathrm{gm}$ decrease in birth weight at the $10 \%$ versus $90 \%$ percentile respectively).

To our knowledge, there is no published study to date that has evaluated the effects of prenatal care at birth weight quantiles accounting for self-selection into prenatal care. The study reported here estimated quantile effects of prenatal care on birth weight for an infant sample from Argentina while explicitly accounting for the endogenous selection of prenatal care. Given the rarity of econometric studies that hsvr evaluated prenatal care effectiveness for less developed countries, the study has also significant implications for assessing the opportunity cost of the low utilization of prenatal care in less developed countries.

\section{Methods \\ Data Sample}

Birth record data was obtained from the Collaborative Latin American Study of Birth Defects (ECLAMC), a South American birth defects surveillance program that has been active since 1967 (Castilla and Orioli, 2004). ECLAMC is affiliated with a large network of hospitals and health professionals (mostly pediatricians) who identify and enroll each newborn with a birth defect in the participating hospitals as well as infants without birth defects who are born in the same hospital and matched by gender and birth date. ECLAMC professionals complete a standard birth record through interviews with the mother and abstraction from medical records prior to hospital discharge after delivery.

The study uses the sample of infants who were born without birth defects between 1995 and 2002 in 34 hospitals in Argentina, the nation with the largest infant sample within

ECLAMC $^{1}$. Due to potential heterogeneities in the effects of prenatal care and other inputs 
by birth defect status, the analysis did not include the infants born with birth defects. For the purpose of this analysis, the sample was limited to singleton live births with recorded birth weights between 500 and 6000 grams and gestational age between 19.5 and 46.5 weeks to avoid recording errors. ${ }^{2}$

\section{Quantile Regression}

The general structure of the birth weight (BW) production model within the quantile regression framework can be characterized as follows (Koenker and Bassett, 1978; Koenker and Hallock, 2001):

$$
\mathrm{BW}=Q\left(\beta_{q} \mathrm{P}+\mathbf{X} \boldsymbol{\lambda}_{q}\right)
$$

where for the $q$ th BW quantile ( $0<q<1), Q$ is the conditional $q$ th quantile of $\mathrm{BW}, \beta$ is the (quantile) effect of prenatal care utilization (P) on quantile $q$ of BW and $\boldsymbol{\alpha}$ is a vector of the quantile effects of the inputs and risk indicators included in vector $\mathbf{X}$ which are also though to $\mathrm{BW}$. Conditional on $\mathbf{X}, \beta$ measures the changes in the $q$ th quantile in BW with a unit change in prenatal care (i.e. with one additional visit or week delayed). In this study, $\mathbf{X}$ included multivitamin use, immunizations, exposure to physical shocks (the majority representing severe traumatism), maternal health, fertility indicators, age and education, and infant's ancestry and sex. ${ }^{3}$ Also included were time effects indicating year of pregnancy occurrence.

\section{Self-Selection into Prenatal Care and Heterogeneity in Effects}

The demand for prenatal care may in part be based on the woman's expectations of the birth outcome given her perceived health risks and her preferences for health and risk taking, which are typically unobserved in available data. Expecting negative outcomes may increase prenatal care demand, which results in underestimation of prenatal care effectiveness when ignoring self-selection (commonly referred to as adverse selection). On the other hand, prenatal care demand is a positive health behavior that is likely to be correlated with other positive behaviors through health preferences and the extent of risk aversion. This favorable self-selection may result in overestimation of prenatal care effectiveness when unaccounted for, due for instance to the lack of measures on all relevant health inputs and behaviors. ${ }^{4}$ The net estimation bias is a function of these opposite self-selection effects, though the adverse self-selection effect is expected to be larger suggesting underestimation of prenatal care effects, as supported by most previous econometric studies. Similar to Ordinary Least Squares (OLS) for "mean effect" models, biased estimates of $\beta$ may be obtained using ordinary quantile regression $(\mathrm{QR})$ models due to the endogenous selection of prenatal care.

The effects of prenatal care on BW quantiles may also vary by $q$ (the quantile order). Specifically, pregnancies with lower health endowments (including genetic, environmental and socioeconomic endowments) are expected to benefit more from prenatal care which could help substitute for the lower endowments in fetal health production. On the other

\footnotetext{
${ }^{1}$ ECLAMC is established as a collaborative voluntary program. The hospitals that are affiliated with ECLAMC are a self-selected sample that represents several socioeconomically and geographically diverse communities. The populations of the provinces of the included hospitals represent about 77\% of the overall Argentinean population. To our knowledge, the ECLAMC sample provides the largest available birth sample in Argentina with high quality and extensive birth record data to conduct such a study. Data collection on prenatal care utilization began in 1995. Verification of collected data was completed through 2002.

2 Only 15 cases were excluded due to these sample restrictions.

${ }^{3}$ Local public clinics in Argentina are available to provide very basic preventive care (including immunizations), yet these do not usually provide prenatal care. Also multivitamin use might be independent in several cases of prenatal care. Therefore, these inputs are not only necessarily a function of prenatal care and that it is why they were added as separate inputs.

${ }^{4}$ Most previous studies have found a net effect of adverse self-selection.
} 
hand, pregnancies with high endowments are expected to benefit less than those with lower endowments given the overall lower health risks expected with pregnancy that can be remedied by prenatal care. This also suggests that stronger self-selection (as well as estimation bias) is expected for the pregnancies with the lower health endowments.

Following Chernozhukov and Hansen (2004,2005 and 2006), the quantile regression with treatment endogenous selection and heterogeneities in treatment effects by quantiles can be modeled as follows:

$$
\mathrm{BW}=Q(\mathrm{P}, \mathbf{X}, \mathrm{U}), \text { where } \mathrm{U} \sim(0,1)
$$

where $Q(\mathrm{P}, \mathbf{X}, q)$ is the conditional $q$ th quantile of $\mathrm{BW}$ and $q$ and $\mathrm{X}$ are as defined above. $\mathrm{U}$ is a rank variable that represents the net "unobserved" endowment level that leads to different $Q$ s for individuals with the same observed characteristics (i.e. $\mathrm{P}$ and $\mathrm{X}$ ), and which allows interpreting quantile effects as treatment effects by the unobserved endowment variable $\mathrm{U}^{5}$

When $\mathrm{P}$ is endogenous, the instrumental variable quantile regression (IVQR) model developed by Chernozhukov and Hansen (2004,2005 and 2006) can be used to obtain consistent estimates of the heterogeneous treatment effects of $\mathrm{P}$ by $q .{ }^{6}$ The model has a set of conditional moments that can achieve identification, yet in essence, the instruments still have to satisfy the typical instrumental variable (IV) conditions of being strongly predictive of the treatment selection and appropriately excludable from the outcome function (see the referenced papers for details). For the $q$ th quantile, the estimation involves a grid search over the parameter $\beta$ to identify the value that would drive the coefficient $(\gamma)$ of the least squares projection of $\mathrm{P}$ on the identifying instruments and $\mathbf{X}$ (call this projection $\mathrm{Z}$ ), as close as possible towards 0 in the following quantile regression:

$$
\mathrm{BW}-\beta \mathrm{P}-Q\left(\mathbf{X} \boldsymbol{\lambda}_{q}(\beta)+Z \gamma_{q}(\beta)\right)
$$

where $\gamma_{q}$ and $\lambda_{q}$, the coefficients of $\mathrm{Z}$ and $\mathrm{X}$ respectively, are a function of $\beta$. The IVQR estimate of the effects of $\mathrm{P}$ on the $q$ th quantile of BW (in equation 1) is the estimate of $\beta$ identified from the grid search that minimizes the absolute value of $\gamma_{q}$ in equation 3. The estimate of $\lambda_{q}$ in equation 1 is the estimate of $\lambda_{q}(\beta)$ from equation 3.

Asymptotic standard errors of the IVQR coefficients were estimated using the formulas provided in the referenced papers. With weak instruments, which are generally considered to have an F-statistic of less than 10 in linear models when testing their joint effects on the selection of the endogenous treatment in the first stage of a 2SLS model (Staiger and Stock, 1997), the usual asymptotic standard errors of the IVQR model for testing the hypothesis of no quantile effects (i.e. $\beta=0$ ) might not provide a good approximation of their finite sample counterparts (Chernozhukov et al, 2007). An asymptotic approximation that involves confidence bounds that are robust for weak instruments is available for this hypothesis in that case. ${ }^{7}$ These weak instrument robust confidence bounds might not necessarily be larger than the usual asymptotic bounds (see Chernozhukov and Hansen, 2008). It is important to note that there is limited guidance on what constitutes weak instruments especially in the

\footnotetext{
${ }_{6}^{5}$ See details in Chernozhukov and Hansen (2005).

${ }^{6}$ The authors note that direct two-stage estimations to deal with endogenous treatments where the first stage is similar to that of the 2SLS model and the second stage uses the predicted treatment value in an ordinary quantile regression (e.g. Arias et al, 2001; Garcia et al, 2001) provides inconsistent estimates when treatment effects are heterogeneous by the quantile order.

${ }^{7}$ See Chernozhukov et al (2007) for details.
} 
quantile regression model. Using the common rule of thumb for 2SLS of a weak instrument having an F-statistic that is less than 10, we estimated 95\% confidence intervals, using the asymptotic approximation that is robust for weak instruments, for the IVQR coefficients of time to prenatal care initiation given that the F-statistic of the instruments was close to 10 as described below when using this measure of prenatal care use.

In addition to the IVQR, we estimated ordinary quantile regression $(\mathrm{QR})$ models assuming exogenous prenatal care use. The standard errors were estimated with bootstrap with 200 replications. Both the IVQR and QR models were estimated for BW quantiles 0.1, 0.25, 0.5, 0.75 and 0.9 .

\section{Mean Effects}

OLS and 2SLS models were estimated to evaluate the effects of prenatal care at BW mean with Huber type robust standard error estimation (Wooldridge, 2002). Given that the F statistic of the joint effects of the instruments on prenatal delay was on the margin of being considered weak, we estimated confidence bounds for the 2SLS prenatal care coefficient that are robust for weak instruments and for heteroscedasticity and autocorrelation of the error terms (Chernozhukov and Hansen, 2008). We also evaluated the exogeneity of prenatal care use using a regression based test that accounts for the robust standard error estimation (Cameron and Trivedi, 2005). ${ }^{8}$

\section{Identifying Instruments}

Indicators of availability of and accessibility to prenatal care including price and supply of prenatal care (such as number of prenatal care clinics or providers per capita) as well as geographic accessibility (e.g. distance from residence to prenatal care clinics) are the preferred instruments for prenatal care use, since they are expected to be strong predictors of use and excludable from the birth weight function (i.e. satisfy the IV assumptions). However, such indicators (especially the price and distance variables) are generally hard to measure, which has been a common challenge for all econometric studies of prenatal care effectiveness. Unfortunately, these specific indicators were not available to include in our study. The typical remedy is to use good proxies of these indicators as instruments when possible. In this study, the instruments for the IVQR and the 2SLS were area-level characteristics (at the province level) that represent overall availability of and accessibility to health care and included population per hospital bed, unemployment rate and rate of uninsured females. These instruments were expected to affect prenatal care utilization and, conditional on the included covariates, to otherwise have no direct or indirect effects on BW. ${ }^{9}$ The population per hospital bed instrument represents a general indicator of the overall distribution and availability of healthcare resources (particularly inpatient healthcare), while the uninsured and unemployment rates represent proxy indicators of the price of prenatal care. ${ }^{10}$

The $\mathrm{F}$ test for the joint significance of the instruments in predicting prenatal care was used. In order to evaluate the appropriateness of excluding the extra instruments from the BW production function, the Hansen test for over-identification restrictions was conducted (Hayashi, 2000).

\footnotetext{
${ }^{8}$ See page 273 .

${ }^{9}$ Similar instruments were included in some of the previous econometric studies evaluating prenatal care effects (e.g. Rosenzweig and Schultz, 1983; Warner, 1995, 1998).

${ }^{10}$ Employment may increase the time costs of seeking prenatal care but may also increase income availability to seek prenatal care. Therefore, the effects of employment are theoretically ambiguous. Individual-level enabling variables such as income may also be evaluated as instruments but they may also be related to health endowments and birth weight through other ways besides prenatal care use. Income was not measured in this sample. Income was not measured in this sample.
} 


\section{Prenatal Care Measures}

Prenatal care was measured alternatively by the number of prenatal care visits and by waiting time prior to initiation of prenatal care. These two utilization modes may have different effects on BW weight and can also have different policy implications. Earlier initiation of prenatal care is expected to increase the return of seeking prenatal care. Using the number of prenatal visits is also important to quantify the productivity per prenatal visit.

\section{Sensitivity Analyses}

Given that certain maternal characteristics such as education are likely to be more endogenous for adolescent mothers compared to older mothers, a second analysis was conducted excluding mothers who are below 20 years of age. ${ }^{11}$ Also, given that some of the prenatal inputs in the BW production function including multivitamin use and immunizations may be endogenous, we estimated alternative models that excluded these inputs from the production function to gauge the sensitivity of the estimates of prenatal care effects to their potential endogenous selection.

\section{Results}

Table 1 includes descriptions, means and standard deviations of the study variables. Prenatal care was initiated around the $18^{\text {th }}$ week of gestation and about 6 prenatal visits were obtained on average. The average BW was about 3278 grams.

\section{Effects of Prenatal Care Utilization}

The OLS, 2SLS, QR and IVQR effects of number of prenatal visits and prenatal care delay are listed in Table 2 and Table 3 respectively for the total sample and the sample excluding adolescent mothers. Table A in the Appendix reports the first stage regressions and Table B reports the full OLS and 2SLS regression results using both the number of prenatal care visits and prenatal care delay. Table $\mathrm{C}$ and Table $\mathrm{D}$ report the full $\mathrm{QR}$ and IVQR regression results respectively when using the number of prenatal care visits measure. ${ }^{12}$

Using the total sample and OLS, prenatal visits increased BW mean by about 24 gm per visit. A larger effect was estimated using 2 SLS with 35 gm increase per visit, yet the exogeneity of prenatal care could not be rejected. The instruments had significant effects on number of prenatal care visits (with an F-statistic of 87) and the over-identifying restrictions could not be rejected.

QR showed that the effects of prenatal care decreased by the quantile order with significantly larger effects at lower versus higher BW quantiles (29 gm versus $11 \mathrm{gm}$ increase in BW at the 0.1 and 0.9 quantile respectively). The IVQR showed larger effects than $\mathrm{QR}$ at the lower order BW quantiles but had generally comparable effects at the higher order quantiles. The effects also decreased by the quantile order under the IVQR. Using IVQR, BW increased by $77 \mathrm{gm}$ per visit at the 0.1 quantile (compared to $29 \mathrm{gm}$ under QR), but only by $10 \mathrm{gm}$ at the 0.9 quantile (not significant).

Slightly smaller mean and quantile effects were observed when adolescent mothers were excluded but virtually the same pattern of results was observed compared to the total sample analysis.

\footnotetext{
${ }^{11}$ This is a common practice in birth outcome production studies (e.g. Grossman and Joyce, 1990; Warner 1995; Rous et al, 2004; Conway and Deb, 2005).

${ }^{12}$ There were generally small differences, if any, in the effects of the other inputs in the production function when using the alternative prenatal care measures.
} 
Using the total sample and OLS, prenatal care delay had a very small and positive signed (i.e. unexpected sign) coefficient. Using 2 SLS, prenatal care delay decreased BW significantly by $30 \mathrm{gm}$ per week. The instruments were less predictive of prenatal care delay than the number of visits (F-statistic of 11), but the prenatal care coefficient was statistically significant using the $95 \%$ confidence intervals that are robust for weak instruments and the over-identification restrictions were similarly not rejected. Unlike prenatal care visits, the exogeneity of prenatal care delay was rejected.

The QR coefficient estimates of prenatal care delay were positive (i.e. unexpected sign) similar to OLS (and generally insignificant) for all evaluated quantiles. Using IVQR, negative coefficients (i.e. expected sign) were observed at all quantiles, with significantly larger effects (in absolute value) at the 0.1 quantile than higher order quantiles (decrease of $139 \mathrm{gm}$ in BW per week delayed at the 0.1 quantile versus $31 \mathrm{gm}$ at the 0.25 and 0.9 quantiles). The IVQR effects were not significant at the 0.1 and 0.25 quantiles using the usual asymptotic standard errors but were significant based on the $95 \%$ confidence intervals that are robust for weak instruments. Similar results for mean and quantile effects were observed when adolescent mothers were excluded from the sample, with generally slightly smaller 2SLS and IVQR coefficients (see Tables 3 and 4).

Table $\mathrm{E}$ and Table $\mathrm{F}$ in the appendix include the effects of prenatal care visits and delay when excluding the multivitamin and immunization inputs from the BW production function. As can be seen, there were minimal effects, if any, of excluding these inputs on the estimated effects of prenatal care use.

\section{Discussion and Conclusion}

The study results support the theory of adverse-self selection into prenatal care, suggested in previous studies, with women at potentially higher risks for adverse infant health outcomes initiating prenatal care earlier and demanding more prenatal care than women at lower risks. Given that several of these risks are unobserved in typically available data sources, ignoring self-selection such as through use of OLS and QR models results in underestimation of prenatal care effectiveness.

Comparing the QR and IVQR results, the study provides further support that adverse selfselection primarily occurs in pregnancies with lower health endowments, which result in births at the extreme left side of the BW distribution. For instance, the IVQR effect of prenatal visits was $168 \%$ larger than the QR estimate at the $0.1 \mathrm{BW}$ quantile (77 versus 29 $\mathrm{gm}$ ), but only $43 \%$ larger at the 0.5 quantile (median), and $7 \%$ smaller at the 0.9 quantile. This implies that the productivity of prenatal care is more underestimated for pregnancies with lower health endowments when ignoring self-selection compared to pregnancies with higher endowments. The results for prenatal care delay also support this argument. This is the first econometric study that clearly highlights the larger estimation bias in prenatal care effectiveness with lower fetal health endowments.

The study shows significant heterogeneities in prenatal care effectiveness by unobserved innate endowments. These heterogeneities are misrepresented by the QR model that ignores self-selection and are masked by mean-effect models (both OLS and 2SLS). The QR model using prenatal care visits does suggest heterogeneities in effectiveness, yet the differences in effects between low and high order quantiles (e.g. 0.1 and 0.9 quantiles) are more pronounced in the IVQR model. This can be seen more clearly when measuring prenatal care use by delay before care initiation, where very minimal differences are suggested under the QR model. Further, there are large discrepancies between "mean effects" and "quantile effects" suggesting that the estimates of "mean effects" of prenatal care are less informative 
when the effectiveness of prenatal care is heterogeneous. In this study, these discrepancies were more pronounced after adjusting for the endogenous selection of prenatal care (i.e. comparing 2 SLS and IVQR versus comparing OLS and OR). Using prenatal care visits, the discrepancy between the "mean" and " 0.1 quantile" effects was $18 \%$ when estimated by OLS and QR respectively, compared to 54\% when estimated by 2SLS and the IVQR model. While these discrepancies are not necessarily generalizable to other estimation scenarios, they do suggest that "mean effects" can be hard to interpret in the presence of significant heterogeneities in treatment effectiveness by certain unobserved characteristics (endowments, abilities, risks, disease severity, etc.), as they can largely mask or overestimate treatment benefits or risks.

The larger benefits of prenatal care at lower BW quantiles were also reported in Abrevaya (2001) who treated prenatal care as exogenous (i.e. using QR). On the contrary, by applying a maximum likelihood finite mixture model, Conway and Deb (2005) concluded that prenatal care utilization improves the BW of infants in normal pregnancies (i.e. infants with greater endowments) but is unlikely to affect the BW of infants in complicated pregnancies. These two studies used different analytical models, but their different interpretations highlight the complexity of modeling empirically the unobserved health endowments and evaluating health input productivity by the endowment level.

The mean effects in this study are generally consistent with those reported in other studies. BW was increased by about $35 \mathrm{gm}$ per visit, which is within the 1 to $50 \mathrm{gm}$ range reported in previous studies (Warner, 1995, 1998; Rous et al, 2004; Jewell, 2007). On the other hand, BW was decreased by about 30 grams per week of prenatal care delay. These results are consistent with Rosenzweig and Schultz $(1983,1988)$ who reported an 80-91 gram decrease in BW with each month elapsed before seeking care, and Conway and Deb (2005) who reported a 30-35 gm decrease in BW with each week before initiating care in the "normal" population based on their finite mixture model and a 70 decrease the white sample based on 2SLS. Other studies have found lower 2SLS estimates [23-37 gm decrease per month (Grossman and Joyce, 1990); 7 gm decrease per week (Warner, 1995)]. The comparison to previous study results is not straightforward given the different samples and analytical specifics, yet it indicates that the estimates of prenatal care effectiveness at BW mean found in this study are rather comparable to those in the literature. The study results do highlight the important of future studies of prenatal care effects on BW in the US using IVQR in order to better understand the productivity of prenatal care in this population.

There were overall small effects of excluding adolescent mothers from the sample, suggesting minimal effects of the likely larger endogenous selection in this group, into some characteristics and inputs that are included in the birth production function, such as education and health risks. Also, the effects of prenatal care virtually remained unchanged when the multivitamin and immunization inputs were excluded from the analysis, suggesting that these inputs are not strongly related to prenatal care in the study sample as hypothesized.

The selected instruments performed well especially in predicting prenatal care visits ( $\mathrm{F}$ statistic of 87 in the total sample). The instruments were weaker in predicting prenatal care delay ( $F$ statistic of 11 in the total sample). One limitation of the used area-level instruments is that they are measured at a single year of the study birth years. These area characteristics will serve as stronger instruments when measured at multiple time periods that cover all the included birth years. ${ }^{13}$ Unfortunately, this data was not available for this study. We also had no access to stronger instruments such as distance to prenatal care clinics or price of prenatal care, which were also not used in previous studies due to the lack of this data. In order to account for the potential weakness of instruments in predicting prenatal care delay, we used 
an inference approach that is robust for weak instruments when evaluating its mean and quantile effects. ${ }^{14}$

In conclusion, the study results suggest that pregnancies with lower health endowments may benefit more from earlier initiation as well as more frequent use of prenatal care than pregnancies with greater endowments. Studies evaluating the effects of prenatal care utilization only at BW mean will mask these heterogeneous effects even when adjusting for self-selection such as by 2 SLS. These heterogeneities can also be masked by QR models that ignore the endogenous selection of prenatal care. Identifying the group of pregnancies with lower health endowments, which are represented by lower BW quantiles, is key for targeting groups that might benefit most from prenatal care. It is therefore important to understand how to better define this group such as by using BW predictors (e.g. regional indicators, maternal health and household characteristics, etc.) to identify prospectively those mothers at higher risk for giving birth to infants at the left margin of the BW distribution and to improve access to prenatal care both through reducing prenatal care delay and increasing the number of visits, especially among this group.

\section{Acknowledgments}

The authors would like to thank Dr Christian Hansen at the University of Chicago for providing the code of the IVQR and helping with the model estimation, as well as Drs. John Brooks, Julie Urmie and John Schneider for their review and discussion of this work.

This work was supported by NIH grants 1R03DE018394, R01 DE-08559 and P50 DE-16215. The authors have no conflicts of interest in this work. The study was approved by the University of Iowa IRB (200501758).

\section{References}

Abadie A, Angrist JD, Imbens G. Instrumental Variables Estimates of the Effect of Subsidized Training on the Quantiles of Trainee Earnings. Econometrica. 2002; 70(1):91-117.

Abrevaya J. The Effects of Demographics and Maternal Behavior on the Distribution of Birth Outcomes. Empirical Economics. 2001; 26(1):247-257.

Arias O, Hallock KF, Sosa-Escudero W. Individual Heterogeneity in the Returns to Schooling: Instrumental Variables Quantile Regression Using Twins Data. Empirical Economics. 2001; 26(1): $7-40$.

Cameron, AC.; Trivedi, PK. Microeconometrics: Methods and Applications. New York: Cambridge University Press; 2005.

Castilla EE, Orioli IM. ECLAMC: the Latin-American collaborative study of congenital malformations. Community Genet. 2004; 7(2-3):76-94. [PubMed: 15539822]

Chernozhukov V, Hansen C. The Effects of 401(k) Participation on the Wealth Distribution: An Instrumental Quantile Regression Analysis. Review of Economics and Statistics. 2004; 86(3):735751.

Chernozhukov V, Hansen C. An IV Model of Quantile Treatment Effects. Econometrica. 2005; 73(1): 245-261.

\footnotetext{
${ }^{13}$ This will also allow including province fixed effects in the birth outcome production function (unless the province-level characteristics are measured on a yearly basis, which would require omitting the pregnancy year fixed effects to achieve identification; when the province-level characteristics are measured more than once per year, such as quarterly or semiannually, province effects can be added to the model while retaining the pregnancy year fixed effects). It is important to note that adding province fixed effects to the OLS birth weight function had no effect on the coefficients of prenatal care visits and delay, and the coefficients of the province indicators were jointly insignificant.

${ }^{14}$ Given that health care availability, measured by population per hospital bed, might affect birth weight through other ways besides its effects on prenatal care (such as through influencing maternal health status and behaviors prior to pregnancy), the 2SLS and IVQR models were re-estimated using only the unemployment rate and rate of uninsured females as instruments. The results were essentially unchanged under this instrument specification. Table $\mathrm{G}$ in the Appendix summarizes these sensitivity results.
} 
Chernozhukov V, Hansen C. Instrumental Quantile Regression Inference for Structural and Treatment Effect Models. Journal of Econometrics. 2006; 132(2):491-525.

Chernozhukov V, Hansen C. The Reduced Form: A Simple Approach to Inference with Weak Instruments. Economics Letters. 2008 forthcoming in.

Chernozhukov V, Hansen C, Jansson M. Inference Approaches for Instrumental Variable Quantile Regression. Economics Letters. 2007; 95(2):272-277.

Conway KS, Deb. P. Is Prenatal Care Really Ineffective? Or, Is the 'Devil' in the Distribution? Journal of Health Economics. 2005; 24(3):489-513. [PubMed: 15811540]

Garcia J, Hernandez PJ, Lopez-Nicolas A. How Wide Is the Gap? An Investigation of Gender Wage Differences Using Quantile Regression. Empirical Economics. 2001; 26(1):149-167.

Grossman M, Joyce TJ. Unobservables, Pregnancy Resolutions, and Birth Weight Production Functions in New York City. The Journal of Political Economy. 1990; 98(5):983-1007.

Hayashi, F. Econometrics. Princeton, NJ: Princeton University Press; 2000.

Jewell RT, Triunfo P. The impact of prenatal care on birthweight: the case of Uruguay. Health Econ. 2006; 15(11):1245-1250. [PubMed: 16786548]

Jewell RT. Prenatal Care and Birthweight Production: Evidence from South America. Applied Economics. 2007; 39(4-6):415-426.

Koenker R, Bassett G. Regression Quantiles. Econometrica. 1978; 46(1):33-50.

Koenker R, Hallock KF. Quantile Regression. Journal of Economic Perspectives. 2001; 15(4):143156.

Liu GG. Birth outcomes and the effectiveness of prenatal care. Health Serv Res. 1998; 32(6):805-823. [PubMed: 9460487]

Rosenzweig, MR.; Schultz, TP. The Behavior of Mothers as Inputs to Child Health: The Determinants of Birth Weight, Gestation, and Rate of Fetal Growth. In: Fuchs, V., editor. Economic Aspects of Health. Chicago: University of Chicago Press; 1982.

Rosenzweig MR, Schultz TP. Estimating a Household Production Function: Heterogeneity, the Demand for Health Inputs, and Their Effects on Birth Weight. The Journal of Political Economy. 1983; 91(5):723-746.

Rosenzweig MR, Schultz TP. The Stability of Household Production Technology: A Replication. Journal of Human Resources. 1988; 23(4):535-549.

Staiger D, Stock JH. Instrumental Variables Regression with Weak Instruments. Econometrica. 1997; 65(3):557-586.

Warner GL. Prenatal Care Demand and Birthweight Production of Black Mothers. The American Economic Review. 1995; 85(2):132-137. [PubMed: 10160525]

Warner GL. Birthweight productivity of prenatal care. Southern Economic Journal. 1998; 65(1):42-63.

Wooldridge, JM. Econometric analysis of cross section and panel data. Cambridge and London: MIT Press; 2002. 
Table 1

Definition, Means and Standard Deviations of Study Variables

\begin{tabular}{|c|c|c|}
\hline Variable name & Definition & $\underset{(\text { SD) }}{\text { Mean }}$ \\
\hline Birth Weight & Birth weight in grams & $\begin{array}{l}3277.91 \\
(542.89)\end{array}$ \\
\hline Visits & Number of prenatal care visits & $\begin{array}{c}6.2 \\
(3.15)\end{array}$ \\
\hline Weeks & $\begin{array}{l}\text { Pregnancy weeks elapsed prior to initiating prenatal } \\
\text { care }\end{array}$ & $\begin{array}{l}17.7 \\
(9.32)\end{array}$ \\
\hline Multivitamin & $\begin{array}{l}\text { Indicator }(0,1) \text { for multivitamin use during } \\
\text { pregnancy }\end{array}$ & $\begin{array}{l}0.05 \\
(0.22)\end{array}$ \\
\hline Varicella & $\begin{array}{l}\text { Indicator }(0,1) \text { for varicella immunization in } 1 \text { st } \\
\text { trimester }\end{array}$ & $\begin{array}{c}0.09 \\
(0.29)\end{array}$ \\
\hline Tetanus & $\begin{array}{l}\text { Indicator }(0,1) \text { for tetanus immunization in } 1 \text { st } \\
\text { trimester }\end{array}$ & $\begin{array}{c}0.05 \\
(0.22)\end{array}$ \\
\hline Physical shocks & $\begin{array}{l}\text { Indicator }(0,1) \text { for exposure to physical shocks } \\
\text { (trauma) in } 1 \text { st pregnancy trimester }\end{array}$ & $\begin{array}{c}0.03 \\
(0.18)\end{array}$ \\
\hline Birth defect history & $\begin{array}{l}\text { Indicator }(0,1) \text { for reporting any child relatives with } \\
\text { the primary birth defects included in the study }\end{array}$ & $\begin{array}{c}0.06 \\
(0.24)\end{array}$ \\
\hline $\begin{array}{l}\text { Difficulty in } \\
\text { conception }\end{array}$ & Indicator $(0,1)$ for reporting difficulty in conception & $\begin{array}{c}0.09 \\
(0.28)\end{array}$ \\
\hline Acute illness & Indicator $(0,1)$ for acute illnesses during pregnancy & $\begin{array}{c}0.36 \\
(0.48)\end{array}$ \\
\hline Chronic illness & $\begin{array}{l}\text { Indicator }(0,1) \text { for any chronic illnesses during } \\
\text { pregnancy }\end{array}$ & $\begin{array}{c}0.16 \\
(0.37)\end{array}$ \\
\hline $\begin{array}{l}\text { First trimester } \\
\text { bleeding }\end{array}$ & Indicator $(0,1)$ for vaginal bleeding in $1^{\text {st }}$ trimester & $\begin{array}{c}0.06 \\
(0.24)\end{array}$ \\
\hline Live births & Live births prior to birth of sampled subject & $\begin{array}{l}1.75 \\
(2)\end{array}$ \\
\hline Miscarriages/stillbirths & Miscarriages and stillbirths prior to sampled subject & $\begin{array}{c}0.25 \\
(0.58)\end{array}$ \\
\hline $\begin{array}{l}\text { Maternal education- } \\
\text { Less than primary } 1\end{array}$ & Indicator $(0,1)$ for below primary school education & $\begin{array}{c}0.15 \\
(0.36)\end{array}$ \\
\hline $\begin{array}{l}\text { Maternal education- } \\
\text { Incomplete secondary } 1\end{array}$ & $\begin{array}{l}\text { Indicator }(0,1) \text { for incomplete secondary school } \\
\text { education }\end{array}$ & $\begin{array}{c}0.26 \\
(0.44)\end{array}$ \\
\hline $\begin{array}{l}\text { Maternal education- } \\
\text { Secondary } 1\end{array}$ & Indicator $(0,1)$ for secondary school education & $\begin{array}{c}0.16 \\
(0.37)\end{array}$ \\
\hline $\begin{array}{l}\text { Maternal education- } \\
\text { University } 1\end{array}$ & Indicator $(0,1)$ for university education & $\begin{array}{c}0.06 \\
(0.25)\end{array}$ \\
\hline Maternal age & Maternal age in years at delivery & $\begin{array}{l}25.93 \\
(6.34)\end{array}$ \\
\hline Maternal age squared & Maternal age in years at delivery squared & $\begin{array}{c}712.5 \\
(352.66)\end{array}$ \\
\hline Native ancestry & Indicator $(0,1)$ for native ancestry & $\begin{array}{c}0.88 \\
(0.33)\end{array}$ \\
\hline $\begin{array}{l}\text { European Latin } \\
\text { ancestry }\end{array}$ & Indicator $(0,1)$ for Latin European ancestry & $\begin{array}{l}0.44 \\
(0.5)\end{array}$ \\
\hline $\begin{array}{l}\text { European non-Latin } \\
\text { ancestry }\end{array}$ & Indicator $(0,1)$ for non-Latin European ancestry & $\begin{array}{c}0.08 \\
(0.27)\end{array}$ \\
\hline
\end{tabular}




\begin{tabular}{|c|c|c|}
\hline Variable name & Definition & $\begin{array}{c}\text { Mean } \\
\text { (SD) }\end{array}$ \\
\hline Other ancestry & Indicator $(0,1)$ for other ancestry & $\begin{array}{c}0.04 \\
(0.19)\end{array}$ \\
\hline Male & Indicator $(0,1)$ for a male sampled subject & $\begin{array}{l}0.51 \\
(0.5)\end{array}$ \\
\hline Pregnancy year $95^{2}$ & Indicator $(0,1)$ for pregnancy in 1995 & $\begin{array}{c}0.13 \\
(0.34)\end{array}$ \\
\hline Pregnancy year $96^{2}$ & Indicator $(0,1)$ for pregnancy in 1996 & $\begin{array}{c}0.1 \\
(0.29)\end{array}$ \\
\hline Pregnancy year $97^{2}$ & Indicator $(0,1)$ for pregnancy in 1997 & $\begin{array}{c}0.11 \\
(0.31)\end{array}$ \\
\hline Pregnancy year $98^{2}$ & Indicator $(0,1)$ for pregnancy in 1998 & $\begin{array}{c}0.13 \\
(0.34)\end{array}$ \\
\hline Pregnancy year $99^{2}$ & Indicator $(0,1)$ for pregnancy in 1999 & $\begin{array}{c}0.15 \\
(0.35)\end{array}$ \\
\hline Pregnancy year $00^{2}$ & Indicator $(0,1)$ for pregnancy in 2000 & $\begin{array}{c}0.12 \\
(0.33)\end{array}$ \\
\hline Pregnancy year $01^{2}$ & Indicator $(0,1)$ for pregnancy in 2001 & $\begin{array}{c}0.13 \\
(0.34)\end{array}$ \\
\hline Pregnancy year $02^{2}$ & Indicator $(0,1)$ for pregnancy in 2002 & $\begin{array}{c}0.03 \\
(0.18)\end{array}$ \\
\hline $\begin{array}{l}\text { Residents per hospital } \\
\text { bed (1995) }\end{array}$ & Number of residents per public hospital bed in 1995 & $\begin{array}{l}463.32 \\
(93.46)\end{array}$ \\
\hline $\begin{array}{l}\text { Female uninsured } \\
\text { (2001) }\end{array}$ & Percentage of uninsured females in 2001 & $\begin{array}{l}39.42 \\
(9.73)\end{array}$ \\
\hline Unemployment (2002) & $\begin{array}{l}\text { Unemployment rate in } 2002 \text { in urban areas of the } \\
\text { province }\end{array}$ & $\begin{array}{l}21.13 \\
(4.21)\end{array}$ \\
\hline
\end{tabular}

Note: Standard Deviations are listed in parentheses.

${ }^{1}$ Omitted category is completed primary school

${ }^{2}$ Omitted category is year 1994 
Table 2

Effects of Number of Prenatal Care Visits on Birth Weight

\begin{tabular}{|c|c|c|c|c|}
\hline Model & \multicolumn{2}{|c|}{$\begin{array}{c}\text { Total Sample } \\
\text { N=2663 }\end{array}$} & \multicolumn{2}{|c|}{$\begin{array}{l}\text { Sample excluding adolescents } \\
\qquad=2274\end{array}$} \\
\hline \multicolumn{5}{|c|}{ Mean Effects } \\
\hline OLS & \multicolumn{2}{|c|}{$\begin{array}{c}23.6^{* * * *} \\
(3.9) \\
\end{array}$} & \multicolumn{2}{|c|}{$\begin{array}{c}21.2^{* * * *} \\
(4.1)\end{array}$} \\
\hline 2 SLS & \multicolumn{2}{|c|}{$\begin{array}{c}35.2 * * * k \\
(11.2)\end{array}$} & \multicolumn{2}{|c|}{$\begin{array}{c}31.5^{* * * *} \| \\
(11.3)\end{array}$} \\
\hline \multicolumn{5}{|c|}{ Quantile Effects } \\
\hline Quantile & $\mathrm{QR}$ & IVQR & QR & IVQR \\
\hline 0.1 & $\begin{array}{c}28.8^{* * *} \\
(6.6)\end{array}$ & $\begin{array}{c}77.1^{* * *} \\
(21.9)\end{array}$ & $\begin{array}{c}26.8^{* * *} \\
(6.9)\end{array}$ & $\begin{array}{l}60.6^{* *} \\
(25.3)\end{array}$ \\
\hline 0.25 & $\begin{array}{c}19.5^{* * *} \\
(4.2)\end{array}$ & $\begin{array}{c}37.8^{* * * *} \\
(14.6)\end{array}$ & $\begin{array}{c}17.1^{* * *} \\
(4.8)\end{array}$ & $\begin{array}{c}22.3 \\
(14.3)\end{array}$ \\
\hline 0.5 & $\begin{array}{c}18.5^{* * *} \\
(4.8)\end{array}$ & $\begin{array}{c}26.4^{* *} \\
(12.1)\end{array}$ & $\begin{array}{c}14.2^{* * *} \\
(4.9)\end{array}$ & $\begin{array}{l}23.0^{*} \\
(12.4)\end{array}$ \\
\hline 0.75 & $\begin{array}{c}19.1^{* * *} \\
(5.3)\end{array}$ & $\begin{array}{c}16.8 \\
(15.1)\end{array}$ & $\begin{array}{c}15.8^{* * *} \\
(5.8)\end{array}$ & $\begin{array}{c}5.3 \\
(16.3)\end{array}$ \\
\hline 0.9 & $\begin{array}{c}11.0^{* *} \\
(5.1)\end{array}$ & $\begin{array}{c}10.2 \\
(15.9)\end{array}$ & $\begin{array}{l}9.2^{*} \\
(5.5)\end{array}$ & $\begin{array}{c}9.5 \\
(14.4)\end{array}$ \\
\hline
\end{tabular}

Note: This table presents the regression coefficients of the number of prenatal care visits in the birth weight production function. Standard errors of coefficients are reported in parentheses. QR is the ordinary quantile regression. IVQR is the instrumental variable quantile regression.

$*$, **, and $* * *$

indicate significance at $\mathrm{p}<0.1, \mathrm{p}<0.05$, and $\mathrm{p}<0.01$ respectively.

$F_{\text {The F }}(3,2629)$ statistic of the significance of instruments in predicting the number of prenatal visits was 87 . The over-identification chi-square (2) statistic was $3.86(\mathrm{p}=0.15)$. The $\mathrm{F}(1,2630)$ statistic of testing the exogeneity of prenatal care visits was 1.17 ( $\mathrm{p}=0.28)$.

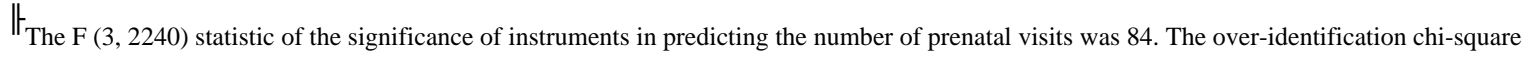
(2) statistic was $1.35(\mathrm{p}=0.51)$. The $\mathrm{F}(1,2241)$ statistic of testing the exogeneity of prenatal care visits was 0.91 ( $\mathrm{p}=0.34)$. 
Table 3

Effects of Delay in Prenatal Care Initiation in Weeks on Birth Weight

\begin{tabular}{lcccc}
\hline Model & $\begin{array}{c}\text { Total Sample } \\
\text { N=2663 }\end{array}$ & \multicolumn{2}{c}{ Sample excluding adolescents } \\
N=2274
\end{tabular}

Note: This table presents the regression coefficients of the number of prenatal care visits in the birth weight production function. Standard errors of coefficients are reported in parentheses. QR is the ordinary quantile regression. IVQR is the instrumental variable quantile regression. The $95 \%$ confidence intervals that are robust for weak instruments are reported in brackets for the 2SLS and the IVQR models.

$*, * *$, and $* * *$ indicate significance at $\mathrm{p}<0.1, \mathrm{p}<0.05$, and $\mathrm{p}<0.01$ respectively.

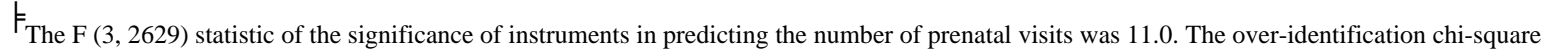
(2) statistic was $4.5(\mathrm{p}=0.11)$. The $\mathrm{F}(1,2630)$ statistic of testing the exogeneity of prenatal care visits was $7.9(\mathrm{p}=0.005)$.

$\|_{\text {The }} \mathrm{F}(3,2240)$ statistic of the significance of instruments in predicting the number of prenatal visits was 8.5 . The over-identification chi-square (2) statistic was $3.1(\mathrm{p}=0.21)$. The $\mathrm{F}(1,2241)$ statistic of testing the exogeneity of prenatal care visits was $5.1(\mathrm{p}=0.02)$. 
Table A

First Stage Regression Coefficients of the 2SLS Model

\begin{tabular}{|c|c|c|}
\hline Variable & $\begin{array}{c}\text { Prenatal Care } \\
\text { Visits }\end{array}$ & $\begin{array}{c}\text { Prenatal Care } \\
\text { Delay }\end{array}$ \\
\hline Intercept & $\begin{array}{c}3.92^{* * *} \\
(0.99)\end{array}$ & $\begin{array}{l}33.6^{* * *} \\
(3.34)\end{array}$ \\
\hline Multivitamin & $\begin{array}{l}0.36^{*} \\
(0.21)\end{array}$ & $\begin{array}{c}-2.47^{* * * *} \\
(0.63)\end{array}$ \\
\hline Varicella & $\begin{array}{c}1.16^{* * *} \\
(0.25)\end{array}$ & $\begin{array}{l}-3.4^{* * * *} \\
(0.81)\end{array}$ \\
\hline Tetanus & $\begin{array}{l}-0.11 \\
(0.24)\end{array}$ & $\begin{array}{l}-0.06 \\
(0.81)\end{array}$ \\
\hline Physical shocks & $\begin{array}{c}0.14 \\
(0.35)\end{array}$ & $\begin{array}{l}-0.25 \\
(0.93)\end{array}$ \\
\hline Birth defect history & $\begin{array}{c}0.13 \\
(0.22)\end{array}$ & $\begin{array}{l}-1.28^{*} \\
(0.67)\end{array}$ \\
\hline $\begin{array}{l}\text { Difficulty in } \\
\text { conception }\end{array}$ & $\begin{array}{l}0.13 \\
(0.2)\end{array}$ & $\begin{array}{l}-0.77 \\
(0.61)\end{array}$ \\
\hline Acute illness & $\begin{array}{l}0.61^{* * *} \\
(0.11)\end{array}$ & $\begin{array}{c}-1.37^{* * *} \\
(0.34)\end{array}$ \\
\hline Chronic illness & $\begin{array}{l}0.51^{* * *} \\
(0.15)\end{array}$ & $\begin{array}{c}-0.98^{* *} \\
(0.42)\end{array}$ \\
\hline First trimester bleeding & $\begin{array}{c}0.63^{* * *} \\
(0.24)\end{array}$ & $\begin{array}{l}-2.17^{* * * *} \\
(0.67)\end{array}$ \\
\hline Live births & $\begin{array}{c}-0.33^{* * *} \\
(0.04)\end{array}$ & $\begin{array}{l}0.99^{* * *} \\
(0.13)\end{array}$ \\
\hline Miscarriages/stillbirths & $\begin{array}{l}0.04 \\
(0.1)\end{array}$ & $\begin{array}{c}0.25 \\
(0.33)\end{array}$ \\
\hline $\begin{array}{l}\text { Maternal education-Less } \\
\text { than primary }\end{array}$ & $\begin{array}{l}-0.34^{* *} \\
(0.17)\end{array}$ & $\begin{array}{l}1.36^{* *} \\
(0.59)\end{array}$ \\
\hline $\begin{array}{l}\text { Maternal education- } \\
\text { Incomplete secondary }\end{array}$ & $\begin{array}{l}0.24^{*} \\
(0.14)\end{array}$ & $\begin{array}{l}-0.4 \\
(0.45)\end{array}$ \\
\hline $\begin{array}{l}\text { Maternal education- } \\
\text { Secondary }\end{array}$ & $\begin{array}{c}0.76^{* * *} \\
(0.17)\end{array}$ & $\begin{array}{c}-0.79 \\
(0.5)\end{array}$ \\
\hline $\begin{array}{l}\text { Maternal education- } \\
\text { University }\end{array}$ & $\begin{array}{l}0.81^{* * *} \\
(0.24)\end{array}$ & $\begin{array}{l}-1.71^{* *} \\
(0.71)\end{array}$ \\
\hline Maternal age & $\begin{array}{l}0.35^{* * *} \\
(0.06)\end{array}$ & $\begin{array}{c}-1.08^{* * *} \\
(0.21)\end{array}$ \\
\hline Maternal age squared & $\begin{array}{c}-0.005^{* * *} \\
(0.001)\end{array}$ & $\begin{array}{l}0.01^{* * *} \\
(0.004)\end{array}$ \\
\hline Native ancestry & $\begin{array}{l}-0.14 \\
(0.18)\end{array}$ & $\begin{array}{c}0.75 \\
(0.55)\end{array}$ \\
\hline European Latin ancestry & $\begin{array}{c}0.27^{* *} \\
(0.12)\end{array}$ & $\begin{array}{l}-0.72^{*} \\
(0.38)\end{array}$ \\
\hline $\begin{array}{l}\text { European non-Latin } \\
\text { ancestry }\end{array}$ & $\begin{array}{c}0.03 \\
(0.19)\end{array}$ & $\begin{array}{c}-0.71 \\
(0.6)\end{array}$ \\
\hline Other ancestry & $\begin{array}{c}0.5 \\
(0.31)\end{array}$ & $\begin{array}{l}0.62 \\
(0.9)\end{array}$ \\
\hline
\end{tabular}

Health Econ. Author manuscript; available in PMC 2010 November 1. 


\begin{tabular}{|c|c|c|}
\hline Variable & $\begin{array}{c}\text { Prenatal Care } \\
\text { Visits }\end{array}$ & $\begin{array}{c}\text { Prenatal Care } \\
\text { Delay }\end{array}$ \\
\hline Male & $\begin{array}{l}-0.06 \\
(0.11)\end{array}$ & $\begin{array}{l}-0.2 \\
(0.34)\end{array}$ \\
\hline Pregnancy year 95 & $\begin{array}{l}0.69^{* *} \\
(0.28)\end{array}$ & $\begin{array}{c}-2.04^{* *} \\
(0.94)\end{array}$ \\
\hline Pregnancy year 96 & $\begin{array}{l}0.98^{* * *} \\
(0.3)\end{array}$ & $\begin{array}{l}-2.74^{* *} \\
(1.06)\end{array}$ \\
\hline Pregnancy year 97 & $\begin{array}{l}0.93^{* * *} \\
(0.3)\end{array}$ & $\begin{array}{l}-2.02^{*} \\
(1.03)\end{array}$ \\
\hline Pregnancy year 98 & $\begin{array}{c}0.94^{* * *} \\
(0.29)\end{array}$ & $\begin{array}{l}-2.94^{* * * *} \\
(0.98)\end{array}$ \\
\hline Pregnancy year 99 & $\begin{array}{c}0.74^{* * *} \\
(0.28)\end{array}$ & $\begin{array}{c}-2.19 * * \\
(0.97)\end{array}$ \\
\hline Pregnancy year 00 & $\begin{array}{c}1.13^{* * *} \\
(0.29)\end{array}$ & $\begin{array}{c}-3.14^{* * * *} \\
(0.99)\end{array}$ \\
\hline Pregnancy year 01 & $\begin{array}{c}0.68^{* *} \\
(0.29)\end{array}$ & $\begin{array}{c}-2.17^{* *} \\
(1)\end{array}$ \\
\hline Pregnancy year 02 & $\begin{array}{l}1.2^{* * * *} \\
(0.36)\end{array}$ & $\begin{array}{l}-4.74^{* * * *} \\
(1.15)\end{array}$ \\
\hline $\begin{array}{l}\text { Residents per hospital } \\
\text { bed (1995) }\end{array}$ & $\begin{array}{c}0.002^{* * * *} \\
(0.001)\end{array}$ & $\begin{array}{c}-0.0003 \\
(0.003)\end{array}$ \\
\hline $\begin{array}{l}\text { Female uninsured } \\
\text { (2001) }\end{array}$ & $\begin{array}{c}-0.08^{* * *} \\
(0.01)\end{array}$ & $\begin{array}{l}-0.05 \\
(0.03)\end{array}$ \\
\hline Unemployment (2002) & $\begin{array}{c}-0.1^{* * * *} \\
(0.02)\end{array}$ & $\begin{array}{c}0.28^{* * * *} \\
(0.05)\end{array}$ \\
\hline$R$ squared & 0.25 & 0.13 \\
\hline $\begin{array}{l}\text { Instrument } F(3,2629) \\
\text { statistic }\end{array}$ & 86.98 & 11.04 \\
\hline
\end{tabular}

Note: This table presents the regression coefficients of the first stage of the 2SLS model for both number of prenatal care visits and prenatal care delay. Standard errors of coefficients are reported in parentheses.

$*, * *$, and ${ }^{* * *}$ indicate significance at $\mathrm{p}<0.1, \mathrm{p}<0.05$, and $\mathrm{p}<0.01$ respectively. 
Table B

Regression Coefficients of the Birth Weight Production Functions

\begin{tabular}{|c|c|c|c|c|}
\hline \multirow[t]{2}{*}{ Variable } & \multicolumn{2}{|c|}{ Prenatal care visits } & \multicolumn{2}{|c|}{ Prenatal care delay } \\
\hline & $O L S$ & $2 S L S$ & $O L S$ & $2 S L S$ \\
\hline Intercept & $\begin{array}{c}2650.3^{* * *} \\
(179.9)\end{array}$ & $\begin{array}{c}2669.7^{* * *} \\
(180.1)\end{array}$ & $\begin{array}{c}2576.5^{* * *} \\
(187.4)\end{array}$ & $\begin{array}{c}3774.4^{* * *} \\
(504.5)\end{array}$ \\
\hline Prenatal Care & $\begin{array}{c}23.6^{* * * *} \\
(3.9)\end{array}$ & $\begin{array}{c}35.2^{* * *} \\
(11.2)\end{array}$ & $\begin{array}{c}0.9 \\
(1.3)\end{array}$ & $\begin{array}{c}-30.2^{* *} \\
(12.0)\end{array}$ \\
\hline Multivitamin & $\begin{array}{c}1.0 \\
(47.5)\end{array}$ & $\begin{array}{l}-6.6 \\
(47.7)\end{array}$ & $\begin{array}{c}18.8 \\
(47.3)\end{array}$ & $\begin{array}{l}-65.8 \\
(61.3)\end{array}$ \\
\hline Varicella & $\begin{array}{c}63.0 \\
(48.8)\end{array}$ & $\begin{array}{c}50.1 \\
(50.3)\end{array}$ & $\begin{array}{l}92.2^{*} \\
(49.3)\end{array}$ & $\begin{array}{l}-11.4 \\
(70.2)\end{array}$ \\
\hline Tetanus & $\begin{array}{c}66.8 \\
(41.7)\end{array}$ & $\begin{array}{c}69.2 \\
(42.0)\end{array}$ & $\begin{array}{c}61.9 \\
(41.3)\end{array}$ & $\begin{array}{c}60.5 \\
(48.1)\end{array}$ \\
\hline Physical shocks & $\begin{array}{c}-106.9 \\
(71.5)\end{array}$ & $\begin{array}{c}-109.2 \\
(70.8)\end{array}$ & $\begin{array}{c}-101.7 \\
(72.5)\end{array}$ & $\begin{array}{c}-111.8 \\
(80.0)\end{array}$ \\
\hline Birth defect history & $\begin{array}{l}-1.5 \\
(43.9)\end{array}$ & $\begin{array}{l}-4.5 \\
(43.9)\end{array}$ & $\begin{array}{c}5.6 \\
(43.9)\end{array}$ & $\begin{array}{l}-32.3 \\
(50.2)\end{array}$ \\
\hline Difficulty in conception & $\begin{array}{c}7.6 \\
(39.5)\end{array}$ & $\begin{array}{c}3.9 \\
(39.4)\end{array}$ & $\begin{array}{c}16 \\
(40)\end{array}$ & $\begin{array}{c}-9.4 \\
(45.3)\end{array}$ \\
\hline Acute illness & $\begin{array}{c}-48.3^{* *} \\
(21.8)\end{array}$ & $\begin{array}{c}-53.4^{* *} \\
(22.2)\end{array}$ & $\begin{array}{c}-36.7^{*} \\
(21.9)\end{array}$ & $\begin{array}{c}-75.2^{* * *} \\
(28.6)\end{array}$ \\
\hline Chronic illness & $\begin{array}{c}8.1 \\
(30)\end{array}$ & $\begin{array}{c}-0.1 \\
(30.7)\end{array}$ & $\begin{array}{c}25.6 \\
(30.2)\end{array}$ & $\begin{array}{l}-4.0 \\
(34.9)\end{array}$ \\
\hline First trimester bleeding & $\begin{array}{c}-87.7^{*} \\
(45.8)\end{array}$ & $\begin{array}{c}-95.6^{* *} \\
(46.1)\end{array}$ & $\begin{array}{l}-69.5 \\
(47.1)\end{array}$ & $\begin{array}{c}-135.7^{* *} \\
(56.8)\end{array}$ \\
\hline Live births & $\begin{array}{c}40.5^{* * * *} \\
(7.5)\end{array}$ & $\begin{array}{c}45.2^{* * *} \\
(8.8)\end{array}$ & $\begin{array}{c}29.9^{* * *} \\
(7.5)\end{array}$ & $\begin{array}{c}61.7^{* * *} \\
(15.2)\end{array}$ \\
\hline Miscarriages/stillbirths & $\begin{array}{c}-38.6^{*} \\
(22.8)\end{array}$ & $\begin{array}{c}-39.1^{*} \\
(22.7)\end{array}$ & $\begin{array}{c}-37.6 \\
(23)\end{array}$ & $\begin{array}{l}-32.2 \\
(24.3)\end{array}$ \\
\hline $\begin{array}{l}\text { Maternal education-Less } \\
\text { than primary }\end{array}$ & $\begin{array}{c}10.7 \\
(33.3)\end{array}$ & $\begin{array}{c}14.0 \\
(33.2)\end{array}$ & $\begin{array}{c}3.1 \\
(33.7)\end{array}$ & $\begin{array}{c}37.3 \\
(40.4)\end{array}$ \\
\hline $\begin{array}{l}\text { Maternal education- } \\
\text { Incomplete secondary }\end{array}$ & $\begin{array}{l}-33.4 \\
(27.2)\end{array}$ & $\begin{array}{l}-38.3 \\
(27.5)\end{array}$ & $\begin{array}{l}-22.9 \\
(27.5)\end{array}$ & $\begin{array}{l}-35.4 \\
(30.7)\end{array}$ \\
\hline $\begin{array}{l}\text { Maternal education- } \\
\text { Secondary }\end{array}$ & $\begin{array}{c}-1.8 \\
(31.1)\end{array}$ & $\begin{array}{l}-14.1 \\
(32.9)\end{array}$ & $\begin{array}{c}24.2 \\
(31.1)\end{array}$ & $\begin{array}{l}-2.2 \\
(35.9)\end{array}$ \\
\hline $\begin{array}{l}\text { Maternal education- } \\
\text { University }\end{array}$ & $\begin{array}{l}-3.5 \\
(45.5)\end{array}$ & $\begin{array}{l}-16.3 \\
(47.4)\end{array}$ & $\begin{array}{c}24.2 \\
(45.2)\end{array}$ & $\begin{array}{l}-32.7 \\
(54.1)\end{array}$ \\
\hline Maternal age & $\begin{array}{l}27.5^{* *} \\
(12.7)\end{array}$ & $\begin{array}{l}22.8 * \\
(13.3)\end{array}$ & $\begin{array}{l}37.9^{* * *} \\
(12.8)\end{array}$ & $\begin{array}{c}3.8 \\
(19.4)\end{array}$ \\
\hline Maternal age squared & $\begin{array}{l}-0.5^{* * *} \\
(0.2)\end{array}$ & $\begin{array}{c}-0.5^{*} \\
(0.2)\end{array}$ & $\begin{array}{c}-0.7^{* * * *} \\
(0.2)\end{array}$ & $\begin{array}{l}-0.2 \\
(0.3)\end{array}$ \\
\hline Native ancestry & $\begin{array}{c}22.5 \\
(35.1)\end{array}$ & $\begin{array}{l}22.9 \\
(35)\end{array}$ & $\begin{array}{c}21.3 \\
(35.3)\end{array}$ & $\begin{array}{c}28.0 \\
(38.9)\end{array}$ \\
\hline European Latin ancestry & $\begin{array}{c}25.6 \\
(23.2)\end{array}$ & $\begin{array}{l}23.7 \\
(23)\end{array}$ & $\begin{array}{c}30.5 \\
(23.3)\end{array}$ & $\begin{array}{l}-2.7 \\
(29.0)\end{array}$ \\
\hline $\begin{array}{l}\text { European non-Latin } \\
\text { ancestry }\end{array}$ & $\begin{array}{l}-58.1 \\
(39.8)\end{array}$ & $\begin{array}{l}-60.5 \\
(39.6)\end{array}$ & $\begin{array}{l}-52.1 \\
(40.6)\end{array}$ & $\begin{array}{l}-85.3^{*} \\
(45.1)\end{array}$ \\
\hline
\end{tabular}

Health Econ. Author manuscript; available in PMC 2010 November 1. 


\begin{tabular}{|c|c|c|c|c|}
\hline \multirow[t]{2}{*}{ Variable } & \multicolumn{2}{|c|}{ Prenatal care visits } & \multicolumn{2}{|c|}{ Prenatal care delay } \\
\hline & $O L S$ & $2 S L S$ & $O L S$ & $2 S L S$ \\
\hline Other ancestry & $\begin{array}{l}-52.5 \\
(55.2)\end{array}$ & $\begin{array}{l}-58.2 \\
(55.4)\end{array}$ & $\begin{array}{l}-41.5 \\
(55.2)\end{array}$ & $\begin{array}{l}-16.7 \\
(60.5)\end{array}$ \\
\hline Male & $\begin{array}{c}94.0^{* * *} \\
(20.6)\end{array}$ & $\begin{array}{c}94.6^{* * *} \\
(20.5)\end{array}$ & $\begin{array}{c}92.9^{* * *} \\
(20.8)\end{array}$ & $\begin{array}{c}86.7^{* * * *} \\
(23.4)\end{array}$ \\
\hline Pregnancy year 95 & $\begin{array}{l}-38.9 \\
(52.9)\end{array}$ & $\begin{array}{l}-47.2 \\
(53.4)\end{array}$ & $\begin{array}{l}-20.2 \\
(53.2)\end{array}$ & $\begin{array}{l}-81.9 \\
(66.8)\end{array}$ \\
\hline Pregnancy year 96 & $\begin{array}{c}41.5 \\
(58.2)\end{array}$ & $\begin{array}{c}29.3 \\
(59.4)\end{array}$ & $\begin{array}{c}68.7 \\
(58.6)\end{array}$ & $\begin{array}{l}-13.5 \\
(76.1)\end{array}$ \\
\hline Pregnancy year 97 & $\begin{array}{c}39.6 \\
(55.6)\end{array}$ & $\begin{array}{c}26.2 \\
(57.2)\end{array}$ & $\begin{array}{l}68.7 \\
(56)\end{array}$ & $\begin{array}{c}3.4 \\
(70.8)\end{array}$ \\
\hline Pregnancy year 98 & $\begin{array}{c}42.7 \\
(55.5)\end{array}$ & $\begin{array}{c}29.5 \\
(57.3)\end{array}$ & $\begin{array}{l}72.5 \\
(56)\end{array}$ & $\begin{array}{l}-25.4 \\
(76.3)\end{array}$ \\
\hline Pregnancy year 99 & $\begin{array}{c}3.4 \\
(54.5)\end{array}$ & $\begin{array}{c}-7.9 \\
(55.8)\end{array}$ & $\begin{array}{c}28.4 \\
(54.8)\end{array}$ & $\begin{array}{l}-45.9 \\
(70.9)\end{array}$ \\
\hline Pregnancy year 00 & $\begin{array}{c}62.4 \\
(54.9)\end{array}$ & $\begin{array}{c}45.3 \\
(58.1)\end{array}$ & $\begin{array}{l}100.2^{*} \\
(55.5)\end{array}$ & $\begin{array}{l}-10.0 \\
(77.9)\end{array}$ \\
\hline Pregnancy year 01 & $\begin{array}{c}87.4 \\
(55.7)\end{array}$ & $\begin{array}{c}74.9 \\
(57.5)\end{array}$ & $\begin{array}{c}115.3^{* *} \\
(55.9)\end{array}$ & $\begin{array}{c}33.2 \\
(73.9)\end{array}$ \\
\hline Pregnancy year 02 & $\begin{array}{l}-10.6 \\
(79.9)\end{array}$ & $\begin{array}{l}-29.3 \\
(82.2)\end{array}$ & $\begin{array}{c}31.9 \\
(80.7)\end{array}$ & $\begin{array}{l}-128.3 \\
(108.2)\end{array}$ \\
\hline$R$ squared & 0.05 & 0.04 & 0.04 & 0.03 \\
\hline
\end{tabular}

Note: This table presents the regression coefficients of the birth weight production model using alternative measures of prenatal care utilization and OLS and 2SLS estimations. Standard errors of coefficients are reported in parentheses.

$*, * *$, and $* * *$ indicate significance at $\mathrm{p}<0.1, \mathrm{p}<0.05$, and $\mathrm{p}<0.01$ respectively. 


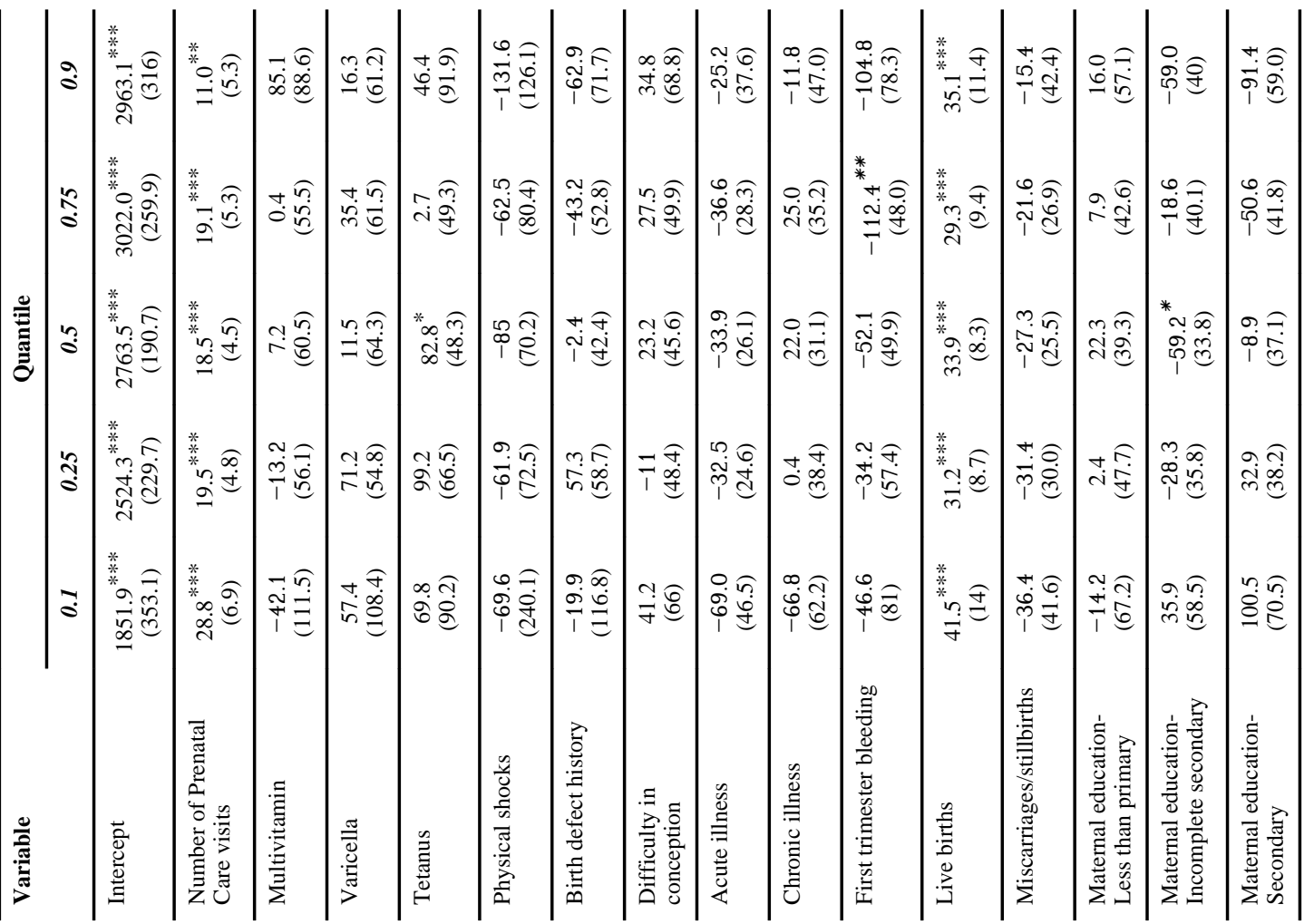




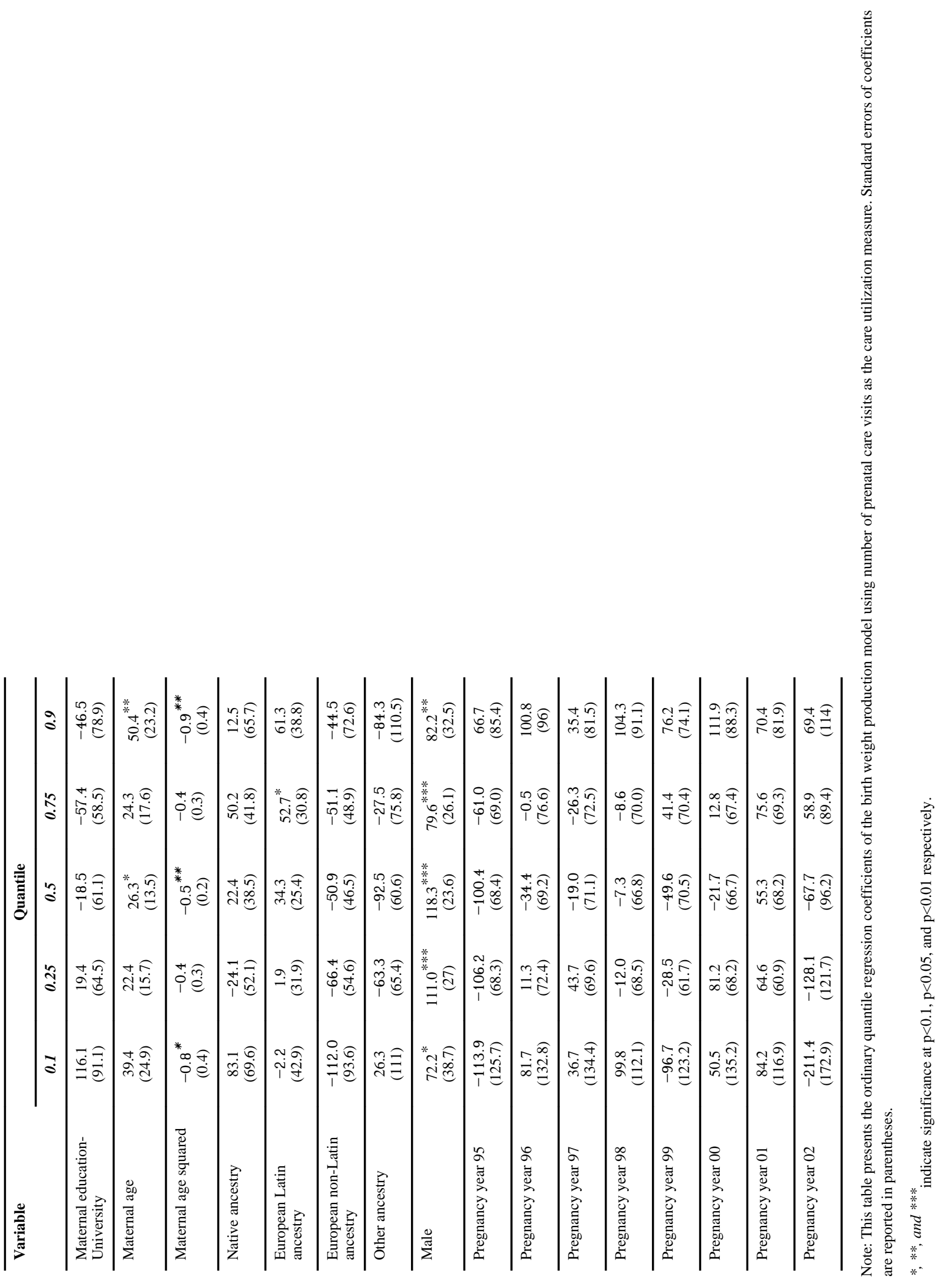




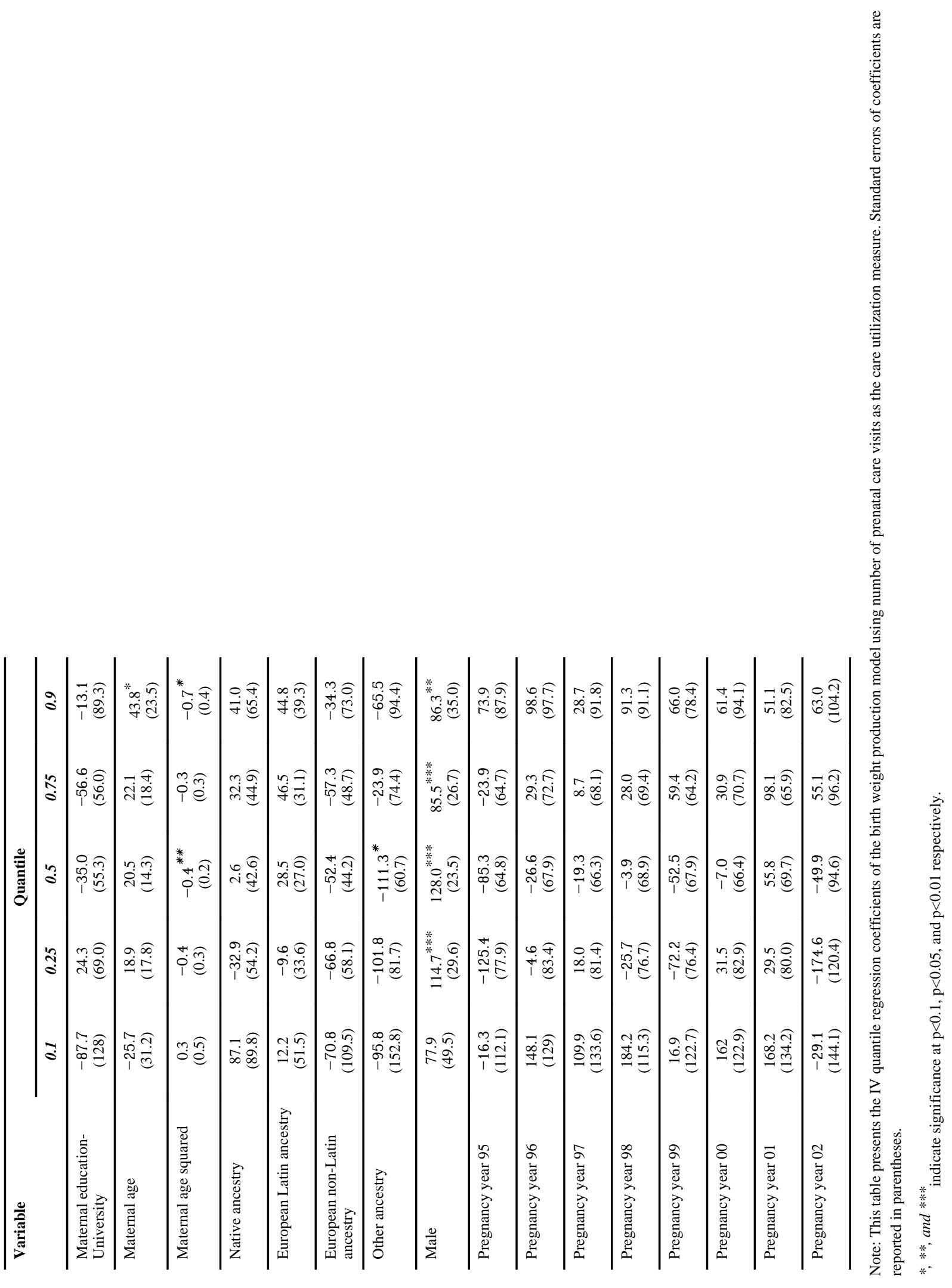


Table E

Effects of Number of Prenatal Care Visits on Birth Weight Including/Excluding the Multivitamin and Immunization Inputs

\begin{tabular}{|c|c|c|c|c|}
\hline Model & \multicolumn{2}{|c|}{ All inputs included } & \multicolumn{2}{|c|}{$\begin{array}{l}\text { Multivitamin and immunization } \\
\text { inputs excluded }\end{array}$} \\
\hline & \multicolumn{4}{|c|}{ Mean Effects } \\
\hline OLS & \multicolumn{2}{|c|}{$\begin{array}{l}23.6^{* * *} \\
(3.9)\end{array}$} & \multicolumn{2}{|c|}{$\begin{array}{l}23.8 * * * \\
(3.9)\end{array}$} \\
\hline \multirow[t]{2}{*}{2 SLS } & \multicolumn{2}{|c|}{$\begin{array}{l}35.2^{* * * *}= \\
(11.2)\end{array}$} & \multicolumn{2}{|c|}{$\begin{array}{l}34.4^{* * * *} \| \\
(11.2)\end{array}$} \\
\hline & \multicolumn{4}{|c|}{ Quantile Effects } \\
\hline Quantile & $\mathrm{QR}$ & IVQR & QR & IVQR \\
\hline 0.1 & $\begin{array}{l}28.8 * * * \\
(6.6)\end{array}$ & $\begin{array}{l}77.1 * * * \\
(21.9)\end{array}$ & $\begin{array}{l}29.8^{* * * *} \\
(7.0)\end{array}$ & $\begin{array}{l}80.0^{* * * *} \\
(18.0)\end{array}$ \\
\hline 0.25 & $\begin{array}{l}19.5 * * * \\
(4.2)\end{array}$ & $\begin{array}{l}37.8 * * * \\
(14.6)\end{array}$ & $\begin{array}{c}20.6^{* * *} \\
(4.8)\end{array}$ & $\begin{array}{l}33.4^{* *} \\
(14.0)\end{array}$ \\
\hline 0.5 & $\begin{array}{c}18.5^{* * *} \\
(4.8)\end{array}$ & $\begin{array}{l}26.4^{* *} \\
(12.1)\end{array}$ & $\begin{array}{c}17.8^{* * * *} \\
(4.5)\end{array}$ & $\begin{array}{c}28.4^{* *} \\
(11.8)\end{array}$ \\
\hline 0.75 & $\begin{array}{l}19.1^{* * *} \\
(5.3)\end{array}$ & $\begin{array}{c}16.8 \\
(15.1)\end{array}$ & $\begin{array}{l}19.3^{* * *} \\
(5.0)\end{array}$ & $\begin{array}{c}16.3 \\
(15.3)\end{array}$ \\
\hline 0.9 & $\begin{array}{l}11.0^{* * *} \\
(5.1)\end{array}$ & $\begin{array}{c}10.2 \\
(15.9)\end{array}$ & $\begin{array}{c}10.7^{* *} \\
(5.2)\end{array}$ & $\begin{array}{c}12.4 \\
(15.2)\end{array}$ \\
\hline
\end{tabular}

Note: This table presents the regression coefficients of the number of prenatal care visits in the birth weight production function using the total sample of 2663 infants. Standard errors of coefficients are reported in parentheses. QR is the ordinary quantile regression. IVQR is the instrumental variable quantile regression.

$* *, * * *$ indicate significance at $\mathrm{p}<0.05$ and $\mathrm{p}<0.01$ respectively.

$F_{\text {The F }}(3,2629)$ statistic of the significance of instruments in predicting the number of prenatal visits was 87 . The over-identification chi-square (2) statistic was $3.86(\mathrm{p}=0.15)$. The $\mathrm{F}(1,2630)$ statistic of testing the exogeneity of prenatal care visits was $1.17(\mathrm{p}=0.28)$.

$\|_{\mathrm{Th}}$ $\mathrm{F}(3,2632)$ statistic of the significance of instruments in predicting the number of prenatal visits when excluding the multivitamin and immunization inputs was 87.9 . The over-identification chi-square (2) statistic was $3.86(\mathrm{p}=0.15)$. The $\mathrm{F}(1,2633)$ statistic of testing the exogeneity of prenatal care visits was $0.98(\mathrm{p}=0.32)$. 
Table F

Effects of Delay in Prenatal Care Initiation in Weeks on Birth Weight Including/Excluding the Multivitamin and Immunization Inputs

\begin{tabular}{|c|c|c|c|c|}
\hline \multirow[t]{2}{*}{ Model } & \multicolumn{2}{|c|}{ All inputs included } & \multicolumn{2}{|c|}{$\begin{array}{l}\text { Multivitamin and immunization } \\
\text { inputs excluded }\end{array}$} \\
\hline & \multicolumn{4}{|c|}{ Mean Effects } \\
\hline OLS & & $\begin{array}{l}0.9 \\
(1.3)\end{array}$ & & $\begin{array}{c}0.7 \\
(1.3)\end{array}$ \\
\hline \multirow[t]{2}{*}{2 2SLS } & & $\begin{array}{c}-30.2 * *= \\
(12.0)\end{array}$ & & $\begin{array}{l}29.5^{* *} \mathbb{H} \\
(11.7) \\
0.0,-9.2]^{* *}\end{array}$ \\
\hline & \multicolumn{4}{|c|}{ Quantile Effects } \\
\hline Quantile & $\mathrm{QR}$ & IVQR & $\mathrm{QR}$ & IVQR \\
\hline 0.1 & $\begin{array}{c}0.1 \\
(2.4)\end{array}$ & $\begin{array}{c}-139.3 \\
(126.1) \\
{[-182.7,-85.0]^{* *}}\end{array}$ & $\begin{array}{l}-0.1 \\
(2.8)\end{array}$ & $\begin{array}{c}-137.8 \\
(118.1) \\
{[-311.9,-73.8]^{* *}}\end{array}$ \\
\hline 0.25 & $\begin{array}{c}0.7 \\
(1.6)\end{array}$ & $\begin{array}{c}-31.3 \\
(23.9) \\
{[-197.5,-0.8]^{* *}}\end{array}$ & $\begin{array}{c}0.6 \\
(1.8)\end{array}$ & $\begin{array}{c}-32.1 \\
(20.7) \\
{[-197.3,-0.4]^{* *}} \\
\end{array}$ \\
\hline 0.5 & $\begin{array}{c}1.6 \\
(1.5)\end{array}$ & $\begin{array}{c}-23.9^{*} \\
(12.7) \\
{[-110.9,17.4]}\end{array}$ & $\begin{array}{c}1.1 \\
(1.5)\end{array}$ & $\begin{array}{c}-23.4^{* *} \\
(11.7) \\
{[-82.2,17.2]}\end{array}$ \\
\hline 0.75 & $\begin{array}{c}2.1 \\
(1.7)\end{array}$ & $\begin{array}{c}-14.4 \\
(13.8) \\
{[-53.8,20.2]}\end{array}$ & $\begin{array}{c}1.8 \\
(1.8)\end{array}$ & $\begin{array}{c}-16.1 \\
(13.3) \\
{[-53.3,21.1]}\end{array}$ \\
\hline 0.9 & $\begin{array}{l}4.3^{* *} \\
(1.8)\end{array}$ & $\begin{array}{c}-30.9^{* * *} \\
(8.8) \\
{[-58.6,183.9]}\end{array}$ & $\begin{array}{l}4.0^{* *} \\
(1.8)\end{array}$ & $\begin{array}{c}-29.3^{* * *} \\
(9.2) \\
{[-50.1,179.2]}\end{array}$ \\
\hline
\end{tabular}

Note: This table presents the regression coefficients of the number of prenatal care visits in the birth weight production function using the total sample of 2663 infants. Standard errors of coefficients are reported in parentheses. QR is the ordinary quantile regression. IVQR is the instrumental variable quantile regression. The $95 \%$ confidence intervals that are robust for weak instruments are reported in brackets for the 2SLS and the IVQR models.

$*, * *$, and ${ }^{* * *}$ indicate significance at $\mathrm{p}<0.1, \mathrm{p}<0.05$, and $\mathrm{p}<0.01$ respectively.

$F_{\mathrm{T}}$

$\mathrm{F}(3,2632)$ statistic of the significance of instruments in predicting the number of prenatal visits was 11.0. The over-identification chi-square (2) statistic was $4.5(\mathrm{p}=0.11)$. The $\mathrm{F}(1,2630)$ statistic of testing the exogeneity of prenatal care visits was $7.9(\mathrm{p}=0.005)$.

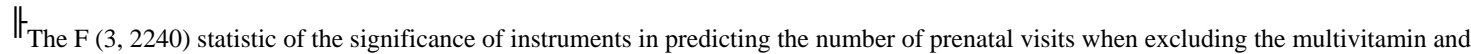
immunization inputs was 11.6. The over-identification chi-square (2) statistic was $4.3(\mathrm{p}=0.12)$. The $\mathrm{F}(1,2633)$ statistic of testing the exogeneity of prenatal care visits was $7.7(\mathrm{p}=0.006)$ 


\section{Table G}

Effects of Prenatal Care Visits and Delay on Birth Weight Excluding the Population per Hospital Bed as an Instrument

\begin{tabular}{|c|c|c|}
\hline \multirow[b]{4}{*}{ Quantile } & Prenatal Care Visits & Prenatal Care Delay \\
\hline & \multicolumn{2}{|c|}{ 2SLS Effects } \\
\hline & $\begin{array}{l}33.3^{* * * *} \\
(11.2)\end{array}$ & $\begin{array}{c}-30.0^{* *} \\
(\mathbf{1 1 . 9 )}\end{array}$ \\
\hline & \multicolumn{2}{|c|}{ IVQR Effects } \\
\hline 0.1 & $\begin{array}{c}76.1 * * * \\
(22.1)\end{array}$ & $\begin{array}{c}-152.4^{* *} \\
(77.5)\end{array}$ \\
\hline 0.25 & $\begin{array}{c}30.2^{* * *} \\
(13.1)\end{array}$ & $\begin{array}{l}-19.6 \\
(13.7)\end{array}$ \\
\hline 0.5 & $\begin{array}{l}27.1^{* *} \\
(12.2)\end{array}$ & $\begin{array}{l}-15.2 \\
(12.6)\end{array}$ \\
\hline 0.75 & $\begin{array}{c}17.0 \\
(15.6)\end{array}$ & $\begin{array}{l}-16.0 \\
(13.7)\end{array}$ \\
\hline 0.9 & $\begin{array}{c}11.3 \\
(16.8)\end{array}$ & $\begin{array}{c}-26.6^{* *} \\
(12.4)\end{array}$ \\
\hline
\end{tabular}

Note: This table presents the 2SLS and IVQR coefficients of the number of prenatal care visits and prenatal care delay in the birth weight production function. Standard errors of coefficients are reported in parentheses.

$* *, * *$ indicate significance at $\mathrm{p}<0.05$ and $\mathrm{p}<0.01$ respectively. 